\title{
Westernisasi Ilmu Dalam Islamic Worldview
}

\author{
Herdina Pratiwi ${ }^{1}$ \\ ${ }^{1}$ Institut Agama Islam Negeri Purwokerto, Indonesia, \\ herdynapratiwi@gmail.com
}

\begin{tabular}{ll}
\hline \hline & Abstract \\
\hline Keywords: & The current technological advances, making various informations \\
Secularization; & easily spread throughout the world. It includes the entry of foreign \\
Knowledge. & culture (Westernization) into the Indonesian State. This \\
& westernization does not only have impact on politics, culture, \\
& region and technology, but in its development, westernization \\
& began to go into science. This research uses a literary study method, \\
& namely data collection activities by conducting a review of various \\
books, literature, notes and reports realting to the topic discussed. & As a result, it can be seen that knowledge Westernization occurs \\
due to the development of shopist who generally have an impact on \\
knowledge in the West. Knowledge in the West as a whole only \\
relies on ratio in describing various things. So the process has \\
strengthened the thesis of the knowledge Westernization. \\
Knowledge in the West has the characteristic of removing the value \\
of belief and spirituality, so this concept breeds secularization. \\
Whereas secularization itself is not only a western worldview that \\
is not Islamic, but also contrary to Islamic teachings. Secularization \\
eliminates revelation as a source of knowledge and negates the role \\
of God in the scientific procces. This is what makes the knowledge \\
Westernization increasingly clear.
\end{tabular}

Kata Kunci:

Westernisasi; kata Sekularisasi; Ilmu

\section{Abstrak:}

Adanya kemajuan tekhnologi sekarang ini, membuat berbagai informasi mudah menyebar ke seluruh penjuru dunia. Termasuk di dalam nya adalah masuknya kebudayaan asing (Westernisasi) yang masuk ke Negara Indonesia. Westernisasi ini tidak hanya berdampak pada bidang politik, budaya, agama, dan teknologi. Namun pada perkembangannya, westernisasi mulai menuju ranah keilmuan. Penelitian ini menggunakan metode studi kepustakaan yaitu kegiatan pengumpulan data dengan melakukan penelaahan terhadap berbagai buku, literature, catatan, serta berbagai laporan yang berkaitan dengan topic yang ingin dibahas. Hasilnya, dapat diketahui bahwa westernisasi Ilmu terjadi akibat adanya perkembangan kaum shopist yang secara umum berdampak pada keilmuan di Barat. Ilmu di Barat secara keseluruhan hanya bersandar pada rasio dalam menguraikan berbagai hal. Jadi proses tersebut telah menguatkan tesis telah terjadinya Westernisasi Ilmu. Ilmu di Barat memiliki karakteristik menghilangkan nilai kepercayaan dan spiritualitas, sehingga konsep ini melahirkan sekularisasi. Sedangkan sekularisasi tidak hanya sebuah western worldview yang tidak islami, tetapi juga berlawanan 
dengan ajaran islam. Sekularisasi melenyapkan wahyu sebagai sumber ilmu dan menafikan Peran Tuhan dalam proses keilmuan. Hal ini lah yang membuat semakin jelas adanya westernisasi ilmu.

\begin{tabular}{cc}
\hline \hline Received : 03 April 2020; Revised: 28 April 2020; Accepted: 14 Juni 2020 \\
\hline \hline $\begin{array}{c}\text { C) Tadris Jurnal Pendidikan Islam } \\
\text { Institut Agama Islam Negeri Madura, Indonesia }\end{array}$ & This is an open access article under the CC-BY-NC license \\
\hline \hline
\end{tabular}

\section{Pendahuluan}

Negara Kesatuan Republik Indonesia merupakan aspek sosio cultural yang sangat beragam. Indonesia adalah bangsa yang memiliki banyak sumber daya dan budaya. Bangsa Indonesia merupakan bangsa yang multi dalam berbagai bidang, seperti multi-agama, multi-budaya dan multi-bahasa. Namun, seiring dengan berjalannya waktu dan berkembangnya teknologi, banyak kebudayaan asing (Westernisasi) yang masuk ke Indonesia kemudian mendorong terjadinya perubahan sosial maupun dalam tatanan masyarakat.

Perubahan sosial dimaknai sebagai terciptanya pola kehidupan sosial yang tidak serasi dengan masyarakat sekitar. Sedangkan perubahan budaya mengarah pada terciptanya budaya baru yang tidak sesuai dengan nilai-nilai budaya yang tumbuh di masyarakat. Westernisasi membawa visi untuk menjadikan kehidupan sehari-hari manusia dipenuhi dengan gaya barat. Pada umunya, westernisasi memiliki jangkauan pada bidang politik, budaya, agama, dan teknologi. Namun pada perkembangannya, westernisasi mulai menuju ranah keilmuan.

Westernisasi dengan usahanya ingin menggusur identitas suatu bangsa yang unik dan menggantinya dengan peradaban barat. Dan jika dilihat pada era millennial ini, banyak sekali generasi emas bangsa yang bersikap "kebaratbaratan". Parahnya, sikap tersebut tidak hanya merasuki ranah sosio-kultural namun juga pada ranah keilmuan. Dimana dalam keilmuan barat tidak selaras dengan islam sehingga dapat merusak nilai dan moral masyarakat.

Ilmu pengetahuan era ini, telah terpengaruhi oleh dunia barat yang secara filsafat telah menganut epistemology secular yang menafikan wahyu sebagai ilmu. Akibatnya, timbulah ilmu yang antagonis terhadap agama. Hal tersebut jelas akan mempengaruhi nilai dan moral masyarakat. Padahal Syed Muhammad Naquib Al-Attas menegaskan bahwa Islam adalah suatu agama yang memiliki cara pandang tersendiri (worldview) yang tulen dan bebas dari berbagai pengaruh dunia barat ${ }^{1}$. Namun, dalam realitanya ilmu yang kebarat-baratan telah merambah hingga pada ilmu agama.

IImu menjadi tantangan serius bagi pemikiran islam yang kontemporer. Hal tersebut dikarenakan keilmuan dijadikan sebagai sesuatu yang rancu oleh Barat. Barat sebagai peradaban dunia telah salah dalam memaknai ilmu yang sesungguhnya. Artinya, Barat yang dengan kemajuannya menghilangkan makna dan tujuan suatu ilmu. Walaupun Barat telah menghasilkan banyak ilmu yang berfaedah, namun tidak dapat dipungkiri Barat disisi lain telah menghasilkan

\footnotetext{
${ }^{1}$ Muhammad Naquib Al-Attas, Konsep Pendidikan Islam: Suatu Rangka Pikir Pembinaan Filsafat Pendidikan Islam, terj. Haidar Bagir (Jakarta: Mizan, 1994), 94-95.
} 
banyak kerancuan dan kerusakan. Selain itu, ilmu pengetahuan yang terpengaruhi dunia Barat telah merusak kehidupan manusia baik secara umum dan khususnya pada ranah spiritual. Problem keilmuan Barat yang demikian akan berpengaruh pada keilmuan Islam dan berimbas pada moral masyarakat.

Dengan demikian, penulis ingin mengulas tentang ilmu yang terkontaminasi oleh cara pandang yang kebarat-baratan dalam worldview islam dan dampaknya dalam kehidupan masyarakat. Sehingga diharapkan, masyarakat dapat memahami bahayanya dan dapat terhindar dari sisi kenegatifan westernisasi ilmu.

\section{Metode}

Metode penelitian yang digunakan penulis adalah studi kepustakaan (Library Research). Library Research adalah serangkaian kegiatan yang berkenaan dengan metode pengumpulan data pustaka, membaca dan mencatat serta mengolah bahan penelitiannya, dimana penelitian tersebut memanfaatkan sumber perpustakaan untuk memperoleh data penelitiannya ${ }^{2}$.

Selain menggunakan perpustakaan sebagai sumber memperoleh data penelitian, penulis juga menggunakan jurnal terbaru terkait judul yang diangkat penulis. Dalam penelitian ini, penulis menggunakan penelitian deskriptif-kritis dengan lebih menekankan pada kekuatan analisis sumber-sumber dan data-data yang ada dengan mengandalkan konsep-konsep yang ada untuk diinterpretasikan berdasarkan tulisan yang mengarah pada pembahasan.

\section{Hasil dan Pembahasan}

\section{A. Westernisasi IImu}

Westernisasi IImu berawal dari munculnya kaum Sophist yang memiliki pengaruh pada keilmuan barat. Sophist berasal dari kata Yunani Sophistikos, Sophistes berate "bijaksana, pintar, halus", dari kata ini Sophist diartikan sebagai seorang yang mencintai kebijaksanaan. Kata Sophist dalam budaya Yunani PraSocrates diartikan sebagai filosof, professor ataupun guru. Namun dalam perkembangannya yaitu abad ke-5 SM, Sophist berubah makna menjadi nama sebuah guru keliling yang mengajar demi mendapat uang ${ }^{3}$.

Pada kemudian hari, Sophist dalam Bahasa Inggris diartikan sebagai orang yang menipu orang lain dengan menggunakan argument yang tidak sah. Hal tersebut didasarkan pada sikapnya yang meminta uang dalam pengajaran. Namun, pada modern ini, Sophist dikatakan sebagai sikap yang menyatakan bahwa kebenaran itu relative adanya. Dalam dunia Barat, kaum Sophist (sufasthaiyyah) dikenal sebagai kelompok yang anti ilmu. Tokoh dari pemikiran Sophist itu diantaranya ada Protagoras, ia adalah tokoh Sophist kelahiran Abdera yang telah menulis buku On the Gods, ia terkenal dengan dictumnya "Human is measure of all things". Selain itu, ada juga tokoh lainnya seperti Gorgius dan Pyyrho.

Berdasar pada pemikiran para tokoh Sophist yang tersistematis, maka Pemikiran Sophist dapat dikelompokkan sebagai berikut ${ }^{4}$ :

\footnotetext{
${ }^{2}$ Mustika Zed, Metode Penelitian Kepustakaan, (Jakarta: Yayasan Obor Nasional, 2004) hlm 2-3

3 Hasib Amrullah, "Sophist dan Pengaruhnya Terhadap Pemikiran Islam Liberal di Indonesia", Tafsiyah: Jurnal Pendidikan Islam Vol.1, No.1 Februari 2017, hlm 73

${ }^{4}$ Hasib Amrullah, Sophist dan Pengaruhnya ......., hlm 73-74
} 
a. Kelompok al-La-adriyyah (Agnostik)

Secara harfiah nama golongan ini berasal dari Bahasa Arab "LaAdri" yang artinya "saya tidak tahu". Kelompok Sophist ini selalu merasa ragu akan kebenaran sesuatu sehingga menolak kemungkinan bahwa seseorang telah mendapatkan ilmu pengetahuan. Nama lain dari golongan ini adalah Agnotik atau agnotisisme yang memiliki definisi keyakinan bahwa tidak mungkin untuk membuktikan ada atau tidaknya Tuhan. Definisi lain dari Agnotisisme adalah ajaran yang baik secara keseluruhan maupun tidak berusaha menyangkal kemungkinan untuk memahami alam semesta.

b. Kelompok al-'Indiyyah (Relativis)

Kelompok ini dinamakan al-'Indiyyah karena penilaiannya yang bersifat subjektif. Dalam bahasa arab "al-'indi" berarti "menurut saya". Kelompok ini dapat menerima kemungkinan dan kebenaran ilmu pengetahuan. Namun, mereka tidak dapat mengakui tujuan ilmu pengetahuan dan kebenaran. Menurut kelompok ini, ilmu pengetahuan dan kebenaran adalah subjektif. Salah satu ajaran dari golongan ini yaitu menegaskan bahwa kebenaran adalah Relative.

c. Kelompok al-'Indiyyah (Skeptis)

Kelompok Sophist ini merupakan kelompok yang keras kepala, yang menafikan segala sesuatu (haqaig al-ashya) dan menganggapnya sebagai fantasi (Ahwam) dan hanyalah semata-mata. Paham ini dalam dunia Barat dikenal dengan paham Skeptisisme, yaitu paham yang menegaskan bahwa tidak dapat seseorang mencapai kebenaran, dan tidak dapat mengetahui realita.

Dalam realita sekarang ini, kelompok Sophist telah berakhir ketika Barat dalam keadaan gelap (dark age). Namun, dasar pemikiran golongan ini masih ada dalam pikiran filsuf Barat sejak zaman klasik sampai kini. Dengan demikian, Pemikiran Sophist memiliki peranan dan pengaruh cukup besar pada perkembangan peradaban Barat pada umumnya dan termasuk di dalamnya Westernisasi Ilmu Pengetahuan Kontemporer.

Kaum Sophist dengan segala pemikirannya telah mempengaruhi ranah keilmuan dunia Barat. Salah satunya yaitu pemikiran kelompok Al-'Indiyyah (Skeptis) yang menafikan realitas segala sesuatu. Syamsudin Arif mencoba memberikan istilah untuk manusia yang terpengaruh pada pemikiran tersebut dengan istilah "Kanker Epistemologis" yakni suatu bentuk penyakit yang dapat mengakibatkan lumpuhnya kemampuan menilai serta gagalnya akal hingga akhirnya akan menggerogoti keimanan dan kepercayaan seseorang. Berdasar hal tersebut, penggunaan istilah "Westernisasi IImu Pengetahuan" mungkin dapat merepresentasikan kondisi Barat yang terhegemoni pada pandangan Saintifik yang secara umum membawa dampak negative dalam bidang epistemology.

Westernisasi sebenarnya merupakan istilah lain dari "Kolonialisasi" hal tersebut didasarkan pada contain nya yang merupakan program penyebaran worldview Barat yang mencakup bidang kultur, tradisi, agama, nilai, kepercayaan, dan sebagainya. Westernisasi muncul dan berkembang karena 
adanya sejarah yang melatarbelakanginya. Diantara latar belakang munculnya westernisasi atau sekularisasi antara lain sebagai berikut ${ }^{5}$ :

1. Secara historis, ilmu pengetahuan yang muncul dan berkembang di Barat bersifat antagonis saintifik terhadap gereja dan Agama (Kristen)

2. Ilmu di Barat dikontruksi atas landasan paradigma empiris, positivistic, materialistic, sekularistik atau dualistic.

3. Adanya asumsi dasar perkembangan ilmu di Barat yang tidak sesuai dengan Islam

4. Menganggap metode positivistic sebagai satu-satunya metode yang absah dan melegitimasi metode yang lain.

Atas problem di atas muncul dan berdirilah Westernisasi IImu yang dalam pandangan islam telah tidak selaras dengan ajaran islam. Kerancuan keilmuan Barat merupakan salah satu akibat dari Identitas Westernisasi. Kerancuan IImu di Barat dapat diidentifikasi dari definisi dan sumbernya. Filsuf Barat seperti John Locke mengemukakan bahwa IImu Pengetahuan merupakan persepsi dari persetujuan atau ketidaksetujuan dari dua ide (Knowledge is the perception of the agreements or disagreement of two ideas), namun yang dimaksud disini ide adalah suatu hasil persepsi manusia yang melalui proses Indrawi ${ }^{6}$. Syed Muhammad Naquib Al-Attas memaparkan bahwa Sekularisasi merupakan suatu pembebasan manusia dar wilayah agama yang kemudian merambah ke metafisika yang mengatur akal dan bahasanya ${ }^{7}$

Selain itu, Van Melsen berusaha menjelaskan ilmu dengan menjelaskan beberapa ciri, diantaranya ilmu harus dapat diverifikasi secara ilmiah, tersusun logis dan sistematis serta bersifat tanpa pamrih karena berkaitan dengan pertanggung jawaban ilmuwan. Dari uraian tersebut, dapat dikatakan bahwasanya cirri tersebut hanya mampu menangkap pengalaman yang bersifat indrawi, sedangkan apapun yang berada diluar itu seperti Tuhan akan ditolak dalam ranah keilmuan. Dengan demikian, dasar keimuan di Barat bertentangan dengan pijakan ilmu dalam Islamic Worldview (Pandangan Islam).

Secara garis besar, Ilmu pengetahuan di Barat bersumberkan pada rasio dan Indrawi yang berdasarkan pada keraguan yang diperkuat oleh spekulasi para filsuf. Barat dengan westernisasinya telah melahirkan berbagai paham secular. Paham secular merupakan paham yang mendorong perubahan masyarakat dari identifikasi yang dekat dengan nilai-nilai agama menjadi nilainilai yang non-agama dan secular ${ }^{8}$. Menurut paham ini, ketika masyarakat "berkembang" maka agama kehilangan kekuatannya di sosial masyarakat. Diantara beberapa paham secular adalah rasionalisme, empirisme, bahkan sampai pada ateisme.

Westernisasi ilmu bermula dari lahirnya beberapa aliran pemikiran tentang ilmu. Rene Descretes, sebagai tokoh rasionalisme menyatakan bahwa adanya peran penting dari rasio yang merupakan satu-satunya cara untuk menguji kebenaran suatu hal. Kemudian aliran empirisme David Hume yang menegaskan bahwa sumber utama ilmu adalah indra dan akal sebagi peran

\footnotetext{
${ }^{5}$ Suharni, "Westernisasi Sebagai Problema Pendidikan Era Modern”, Jurnal Al-ljtimaiyyah Vol. 1, No. 1, 2015, hlm 78-80

6 Mahbub Setiawan, Tesis: Kritik Terhadap Epistemologi Barat Modern : Perspektif Islamic Worldview, Surakarta: UMS, hlm 7

7 Nur Hasan, "Kritik Islamic Worldview Syed Muhammad Naquib Al-Attas terhadap Western Worldview", Maraji' : Jurnal Studi Keislaman Vol. 1 No. 1, September 2014, hlm 127

${ }^{8} \mathrm{Https} / / /$ id.m.wikipedia.org/wiki/sekularisasi, diakses tanggal 2 November 2019 pukul $12.27 \mathrm{WIB}$
} 
nomor dua setelahnya. Dengan begitu, maka jelas dapat ditegaskan bahwa sumber ilmu di Barat hanya berdasarkan rasio dan indra. Dengan demikian, pemikiran mereka sama dengan paham secular dalam tujuannya, yaitu memisahkan agama dan wahyu sebagai sumber utama ilmu dalam proses keilmuan.

Problem keilmuan Barat seperti yang telah dijelaskan di atas, memiliki pengaruh yang cukup besar dalam obyek kajian ilmu. Hal tersebut dikarenakan Barat hanya membatasi objek kajiannya pada sesuatu yang empiris, dapat diamati secara indrawi, fisik, materi serta bersifat eksternal. Maksudnya adalah segala sesuatu yang tidak dapat dibuktikan secara empiris akan dikeluarkan dari ranah ilmu, meskipu hal tersebut benar namun dinilai tidak berarti karena tidak dapat diukur. Dari sini kemudian para ilmuwan Barat berusaha mencari istilah yang merepresentasukan problematika penggunaan rasio dan indra sebagai sumber ilmu yang disisi lain tentu saja menafikan adanya kekuasaan Tuhan dalam berbagai hal. Selain itu, dalam Islam proses keilmuan selalu melibatkan Allah (Tuhan) sebagai sumber ilmu. Lain halnya dengan ilmu di Barat yang prosesnya diyakini sebagai murni upaya manusia ${ }^{9}$. Ilmu dalam islam erat kaitannya dengan adab, sedangkan ilmu di Barat tidak demikian.

Dengan demikian, dapat disimpulkan bahwa IImu di Barat secara keseluruhan hanya bersandar pada rasio dalam menguraikan berbagai hal. Jadi proses tersebut telah menguatkan tesis telah terjadinya Westernisasi IImu. IImu di Barat memiliki karakteristik menghilangkan nilai kepercayaan dan spiritualitas, sehingga konsep ini melahirkan sekularisasi. Syed Muhammad Naquib Al-Attas menyatakan bahwasanya islam menolak penerapan apapun dari konsep secular (sekularisasi) $^{10}$. Hal tersebut dikarenakan Secular tidak hanya menegasikan terhadap Islamic Worldview, namun juga menyatakan penentangannya terhadap islam. Sekularisasi tidak hanya sebuah western worldview yang tidak islami, tetapi juga berlawanan dengan ajaran islam. Sekularisasi melenyapkan wahyu sebagai sumber ilmu dan menafikan Peran Tuhan dalam proses keilmuan. Hal tersebut memberikan dampak besar pada proses keimuan. IImu menjadi problematic, nilai spiritual terkikis, dan ilmu agama menjadi antagonis. Inilah Problem Keilmuan di Barat yang melahirkan Westernisasi Ilmu yang dampaknya sangat besar di dunia, khususnya jika diterapkan oleh umat muslim.

\section{B. Dampak Westernisasi Ilmu : Perspektif Islamic Worldview}

IImu Pengetahuan merupakan landasan bagi semua aktivitas manusia. Perbuatan tanpa ilmu pengetahuan hanya akan menimbulkan kerusakan. Walaupun fitrah manusia ialah tidak jahat, namun ada kemungkinan berbuat kekacauan karena kejahilannya. Kejahilan dalam Kamus Besar Bahasa Indonesia (KBBI) memiliki arti kebodohan. Namun, dalam konsepsi islam, kejahilan memiliki beberapa definisi, yaitu :

1) Kejahilan ringan, yaitu kurangnya ilmu pengetahuan tentang apa yang seharusnya diketahui.

\footnotetext{
${ }^{9}$ Sarjuni, “Konsep IImu Dalam Islam dan Implikasinya Dalam Praktik Kependidikan”, Vol. 1 No. 2, Agustus 2018, hlm 56

${ }^{10}$ Nur Hasan, "Kritik Islamic Worldview Syed Muhammad Naquib Al-Attas terhadap Western Worldview", Maraji' : Jurnal Studi Keislaman Vol. 1 No. 1, September 2014, hlm 140
} 
2) Kejahilan berat, yaitu keyakinan yang bertentangan pada fakta atau realita, memahami sesuatu yang berbeda dengan sesuatu itu sendiri, maupun melakukan sesuatu dengan cara yang berbeda dengan yang seharusnya.

Berdasarkan kedua konteks tersebut dapat dikatakan bahwa kekacauan, kerusakan maupun kerusuhan manusia disebabkan adanya kejahilan. Dalam kaitannya dengan Westernisasi IImu, Keilmuan di Barat telah salah dalam memaknai ilmu. Pandangan Barat menyatakan manusia tidak memerlukan wahyu sebagai sumber ilmu padahal dalam Islamic Worldview ilmu bersumberkan pada wahyu dan kenabian.

Bahayanya, cara pandang ilmu yang kebarat-baratan (Westernisasi IImu) telah merasuk dan merusak pemikiran umat islam. Problem keilmuan di Barat yang tekah merambah ke berbagai penjuru dunia memiliki dampak loss of adab (hilangnya adab pada diri manusia). Hal tersebut dikarenakan ilmu di Barat terpengaruhi oleh paham sekularisasi yang berusaha membebaskan seseorang dari kungkungan agama dan akalnya. Padahal, dalam agama islam erat kaitannya dengan moral dan adab, adanya westernisasi ilmu menjadikan seseorang kehilangan moral dan adabnya.

Selain itu, Westernisasi IImu berimbas pada hilangnya sikap adil dan kebingungan intelektual yang tercermin pada ketidakmampuan menemukan distingsi ilmu yang benar dengan ilmu sekuler. Hal tersebut berimplikasi pada muslim yang kehilangan arah dan tujuan dalam aktivitas keilmuan seperti observasi, penelitian dan yang lainnya. Dengan ini berakibat pada kezaliman dan kebodohan dibuktikan dengan adanya campur tangan muslim dalam bagian eksploitasi kekayaan alam, merusak daratan, lautan maupun udara. IImu yang seharusnya menciptakan kedamaian, dalam kenyataannya justru membawa kekacauan dengan epistemology sekularnya yang beranggapan keraguan adalah sarana yang tepat untuk mencapai kebenarra. IImu yang seharusnya menciptakan kedamaian, dalam kenyataannya justru membawa kekacauan dengan epistemology sekularnya yang beranggapan keraguan adalah sarana yang tepat untuk mencapai kebenaran.

Kemudian, telah kita ketahui problem keilmuan di Barat ialah sumbernya yang berdasarkan rasio dan indra, menafikan wahyu sebagai sumber ilmu serta melenyapkan peran Tuhan dalam berbagai hal. Paradigm tersebut telah berdampak pada tumbuh dan berkembangnya paham Ateisme di berbagai wilayah. Ateisme adalah sebuah pandangan filosof yang menyatakan bahwa keberadaan Tuhan adalah tidak nyata. Ateisme merupakan salah satu paham secular dimana dalam secular ilmu tidak bersumber pada wahyu dan menafikan peran Tuhan di dalamnya. Salah satu ilmuan yang termasuk dalam Ateisme adalah Charles Darwin. la menyatakan bahwa dalam Penciptaan Alam Semesta yang berperan adalah Teori Evolusi dan Seleksi Alamnya bukan atas penciptaan Tuhan ${ }^{11}$. Dengan meluasnya Westernisasi IImu maka dapat menimbulkan semakin berkembangnya Ateisme di dunia ini.

\section{Ilmu Pengetahuan dalam Islam}

Dalam rangka lebih memahami mengenai Westernisasi IImu maka akan dijelaskan mengenai IImu Pengetahuan dalam Islam yang sangat berkebalikan dengan IImu dalam Worldview Barat. Dalam Islamic Worldview, ilmu adalah

\footnotetext{
${ }^{11}$ Fahri Hidayat, "Pengembangan Paradigma Integrasi IImu: Harmonisasi IImu dan Sains dalam Pendidikan", Jurnal Pendidikan Islam, Vol. IV, No. 2 2015, hlm 310
} 
pengetahuan mendalam yang merupakan hasil ijtihad ilmuwan muslim atas persoalan yang bersifat duniawi dan ukhrawi yang bersumberkan pada Wahyu Allah ${ }^{12}$. Wahyu Allah disini mencakup Al-Qur'an dan Hadits. Kedua-nya merupakan sumber IImu yang berfungsi sebagai petunjuk bagi umat manusia, yang didalamnya juga meliputi petunjuk tentang ilmu dan aktivitas ilmiah.

Dalam penjelasan Al-Qur'an dan Hadits sesungguhnya mengandung makna paradigma ilmu dalam islam yang teosentris. Teosentris merupakan suatu keadaan dimana Tuhan menjadi pusat segala kekuatan dan kekuasaan ${ }^{13}$. Oleh karena itu, perkembangan ilmu dan agama dalam islam berjalan harmonis dan seiring. Misalnya saja, Ibnu Rusyd, selain ahli hukum islam penulis kitab Bidayah al-Mujtahid juga ahli kedokteran yang menyusun kitab al-Kulliyat fi sl-Thibb ${ }^{14}$.

Lain halnya dengan Peradaban Barat yang berusaha mengungkapkan bahwa IImu hanya bersumberkan rasio dan indra tanpa adanya wahyu. Hal tersebut menimbulkan hubungan disharmonis antara ilmu dan agama. Yang kemudian memnimbulkan dampak krusial karena menjadikan ilmu yang sekuler dan menjauhkan diri dari agama. Akibatnya akan terjadi kesalahan besar jika diterapkan oleh umat muslim. Oleh karena itu, para ilmuan dan filsuf muslim harus kembali membangun ilmu pengetahuan yang sudah terlanjur terpengaruh oleh relativisme dan skeptisisme ${ }^{15}$

\section{Kesimpulan}

Peradaban Barat dengan pola pemikirannya telah memasuki bidang keilmuan Islam. Barat dengan peradabannya itu telah mempengaruhi makna dan interpretasi ilmu dengan epistemology sekularnya. Epsitemologi inilah yang telah melenyapkan wahyu sebagai sumber ilmu. Dengan demikian ilmu menjadi tak tentu arah. selain itu, epistemology ini menimbulkan individu atau masyarakat kehilangan adabnya (loss of adab) sehingga muncullah berbagai kekacauan dan kerusakan.

Hal tersebut berbeda dengan Islam yang memiliki konsep keilmuan yang identik. Keilmuan Islam bersumberkan Al-Qur'an dan Hadits dan worldview yang membangunnya adalah Islamic Worldview. Al-Qur'an member semangat untuk melakukan aktivitas ilmiah dan sebagainya. Kemudian, Islam menegaskan bahwa dalam mencapai ilmu pengetahuan dan sains yang lebih tinggi, bisa dicapai dengan epistemology yang sekuler. Artinya, ilmu pengetahuan dan sains dapat diraih dengan tetap berpegang teguh atau berbasis pada konsep Tuhan.

\footnotetext{
12 Muhammad Kosim, "Ilmu Pengetahuan Dalam Islam”, Jurnal Tadris, Vol. 3, No. 2, 2008, hlm 122.

${ }^{13}$ M.Gufron, "Transformasi Paradigma Teologi Teosentris Menuju Antroposentris: Telaah atas pemikiran Hasan Hanafi”, Millati: Journal Of Islamic Studies and Humanities, Vol. 3, No. 1, 2018, hIm 157

${ }_{14}^{14}$ Muhammad Kosim, “Ilmu Pengetahuan Dalam Islam”, Jurnal Tadris , Vol. 3, No. 2, 2008, hlm 124

${ }^{15}$ Haidar Bagir, Buku Saku Filsafat Islam, (Jakarta: Mizan, 2005) hlm 48
} 


\section{DAFTAR PUSTAKA}

Al-Attas , Muhammad Naquib.1994. Konsep Pendidikan Islam: Suatu Rangka Pikir Pembinaan Filsafat Pendidikan Islam, terj. Haidar Bagir . Jakarta: Mizan

Az-Zarnuji. 1978. Ta'lim Al-Muta'alim, terj. Aliy As'ad . Kudus : Menara Kudus

Bagir, Haidar . Buku Saku Filsafat Islam. Jakarta: Mizan

Fahri Hidayat. "Pengembangan Paradigma Integrasi IImu: Harmonisasi IImu dan Sains dalam Pendidikan", Jurnal Pendidikan Islam, Vol. IV, No. 22015

Hasib Amrullah. "Sophist dan Pengaruhnya Terhadap Pemikiran Islam Liberal di Indonesia", Tafsiyah: Jurnal Pendidikan Islam, Vol.1, No.1 Februari 2017

Https://id.m.wikipedia.org/wiki/sekularisasi, diakses tanggal 2 November 2019 pukul 12.27 WIB

M. Nahwi. Tt. Kamus Lengkap 950 Triliyun: Inggris Indonesia Indonesia-Inggris. Surabaya: Mitra Pelajar

M.Gufron. "Transformasi Paradigma Teologi Teosentris Menuju Antroposentris: Telaah atas pemikiran Hasan Hanafi", Millati: Journal Of Islamic Studies and Humanities, Vol. 3, No. 1, 2018

Mahbub Setiawan. "Kritik Terhadap Epistemologi Barat Modern : Perspektif Islamic Worldview" Tesis naskah publikasi, Surakarta: UMS

Muhammad Kosim. "Ilmu Pengetahuan Dalam Islam (Perspektif FilosofisHistoris", Jurnal Tadris, Vol. 3, No. 2, 2008

Mundiri. 1994. Logika. Jakarta: PT Raja Grafindo Persada

Mustika Zed. 2004. Metode Penelitian Kepustakaan. Jakarta: Yayasan Obor Nasional

Nur Hasan. "Kritik Islamic Worldview Syed Muhammad Naquib Al-Attas terhadap Western Worldview", Maraji' : Jurnal Studi Keislaman, Vol. 1 No. 1, September 2014

Rosita Baiti \& Abdur Razzaq, "Esensi Wahyu dan Ilmu Pengetahuan”, Jurnal Wardah, Vol 18, No. 2, 2017

Sarjuni. "Konsep IImu Dalam Islam dan Implikasinya Dalam Praktik Kependidikan". Al-Fikri : Jurnal Studi dan Penelitian Pendidikan Islam, Vol. 1 No. 2, Agustus 2018

Suharni. "Westernisasi Sebagai Problema Pendidikan Era Modern", Jurnal Alljtimaiyyah, Vol. 1, No. 1, 2015 